\title{
A violência nossa de cada dia
}

Igor Zanoni Constant Carneiro Leão*

Ademir Clemente**

RESUMO - O objetivo desse texto é traçar algumas formas cotidianas de violência pertencentes à vida comum dos habitantes dos grandes centros urbanos no Brasil, mostrando sua multiplicidade e suas implicações políticas e institucionais num mundo que vive uma grave crise moral.

Palavras-chave: Violência. Cotidiano e relações interpessoais. Urbanização.

A violência, sob múltiplas formas, há muito se tornou endêmica nos grandes centros urbanos brasileiros. Normalmente liga-se esse fenômeno à disseminação do tráfico, mas um exame atento revela muitas questões em torno desse consenso. Neste texto, utilizamos dados reais vividos no contexto da vida de um casal que aparece sob os nomes fictícios de João e Maria e de sua empregada de muitos anos, Marta.

O casal mora em um bairro de classe C em Curitiba, próximo a uma invasão onde mora Marta, e que vem sendo aos poucos regularizada com muita dificuldade pela prefeitura do município limítrofe. Quase todos os dias há notícias em casa envolvendo episódios de violência nesses espaços urbanos. À guisa de exemplo, há algumas semanas um grupo de jovens invadiu uma padaria para assaltá-la e foi dominado pelo dono do estabelecimento. A polícia prendeu os jovens, mas uma semana depois estavam soltos e voltaram para matar este homem. Aparentemente, a prisão dos jovens não protegeu a população e ter dominado os assaltantes foi um ato tão inútil quanto deixar-se assaltar por eles.

Outro caso. $\mathrm{Na}$ invasão onde mora Marta, um grupo também de jovens invadiu outro estabelecimento e foi contido pela população que chamou a polícia de outro município próximo. Segundo contam alguns presentes, esta argumentou que ela era de outro município, que não poderia prender os jovens e que teria sido melhor uma punição exercida pela própria população. Esses casos indicam muitas coisas. Por exemplo, a polícia deve cumprir o seu papel de prender, dando um destino policial aos delituosos e deixando correr o processo judiciário posterior. É inaceitável que ela pense em punição pela própria sociedade.

\footnotetext{
* Doutor em Economia pela UNICAMP. Professor Associado do Departamento de Economia da Universidade Federal do Paraná. Endereço eletrônico: igorzaleao@yahoo.com.br

** Pós-doutor em Economia pela London University. Professor Adjunto do Departamento de Contabilidade da Universidade Federal do Paraná. Endereço eletrônico: ademir@ufpr.br.
} 
Voltaríamos assim a um tempo em que a defesa desta sociedade cabe a ela mesma, esvaziando os poderes públicos.

Mas, na verdade, talvez pelos jovens terem prerrogativas legais é um fato que a punição a eles torna-se difícil, e que eles voltam facilmente à rua depois de se envolverem com algum incidente. Há aí uma importante questão envolvendo o tratamento de crianças e adolescentes num quadro legal do Estatuto da Criança e de Adolescente que não pode ser adequadamente cumprido devido, provavelmente, à precariedade do sistema penal como um todo.

Esse tipo de acontecimento repetiu-se ontem. Um jovem de moto baleou outro jovem que se refugiou, ferido, numa casa, sendo atendido medrosamente por seus moradores, que chamaram a polícia. O rapaz na moto talvez estivesse cobrando uma dívida de drogas ou cometendo outro ato parecido. O fato é que era muito jovem para o que estava fazendo. Provavelmente estivesse sendo usado pelo tráfico devido às já mencionadas prerrogativas legais que os jovens têm e que os tornam uma peça importante no jogo do tráfico. Sua juventude, longe de protegê-los, parece, no contexto econômico e social em que vivem, expôlos ainda mais à violência. Não estamos condenando tratamento diferenciado a jovens e crianças, mas chamando atenção para a precariedade desse tratamento na atualidade.

A violência que os jovens envolvidos com tráfico sofrem pôde ser percebida há algumas semanas num violento homicídio de um adolescente num local próximo. Mas casos semelhantes ocorrem em toda a região metropolitana de Curitiba. Vimos na televisão uma dívida de droga ser cobrada resultando na chacina de uma família que possuía duas crianças pequenas que também morreram na mesma. É provável que a violência, aí, vise coibir terminantemente qualquer dívida semelhante, mas também tenha tido como preocupação não deixar testemunhas.

Dois pontos podem ser levantados a partir daí. O tráfico é extremamente rigoroso. Quem se envolve com ele não pode, em hipótese alguma dever dinheiro. Isso leva a uma violência posterior de devedores, que têm de fazer qualquer coisa para levantar fundos para pagar suas dívidas ou serão quase sem dúvida mortos. Esta situação penaliza especialmente jovens vivendo situações precárias em contextos familiares pobres e que se envolvem com a droga por muitos motivos. Um deles é a solidariedade natural que se cria por muitas razões entre os jovens, e que a droga também propicia inclusive por seus atrativos psicológicos e sociais. 
Se o tráfico é rigoroso, o mesmo não parece acontecer com as instituições da sociedade civil, ou não teríamos ouvido o conselho de que a comunidade no assalto atrás relatado fizesse justiça com as próprias mãos. Parece haver, na verdade, um descompromisso para com obrigações que são próprias de cada instituição, jogando de volta os problemas que ocorrem para a sociedade. Este é um tipo de recuo do estado que tem como sua função precípua conter a violência civil ao mesmo tempo defendendo os civis de sua agressão mútua.

É fácil fazer essas críticas. Mas é difícil viver nesses espaços urbanos. As escolas onde os filhos de Maria e João estudaram e das quais já saíram, necessariamente, estão sitiadas pelo tráfico e pela violência. De manhã é comum encontrar no pátio das escolas camisinhas usadas, seringas e sujeira de todo tipo que as faxineiras sempre em número insuficiente se expõem a limpar. Nas ruas próximas a oferta de drogas é muito evidente. É um dado importante a disseminação do crack, uma droga barata de efeitos rápidos e intensos e que vicia em tempo curto. Os jovens atingidos pelo crack entram num círculo infernal de dependência psicológica, necessidades financeiras e exposição aos donos do tráfico revolucionando toda sua vida social. Dificilmente esses jovens se recuperarão, exceto em casos de muito cuidado familiar e comunitário.

Esses cuidados não podem ser tratados pela polícia ou pelos educadores sociais nos estabelecimentos para jovens infratores, verdadeiros infernos para todos os que têm ali seu dia a dia. É difícil pensar em uma solução. Para João, que é professor numa dessas escolas, a situação mostra-se difícil porque os alunos em geral são crescentemente rebeldes, avessos às aulas e às avaliações, não aceitam conversas sobre seus problemas, chegando mesmo a agredir professores e funcionários da escola. Se pensarmos a escola como uma saída parece ser uma saída que precisa ser reconstruída de uma forma criativa e pouco clara.

Some-se a isso o fato de que crianças e adolescentes devem ter um espaço protegido e livre para desenvolver seu potencial humano e conhecer-se como pessoas, um espaço que passa pela escola, mas não se esgota nela. É preciso pensar numa reengenharia para a vida desses jovens, na qual possam desenvolver valores éticos válidos que não possam ser derrubados pelo atrativo do crack. Por outro lado, o trabalho não é visto de forma compensadora em muitos casos dos que se envolvem com o tráfico.

Mesmo com o bom desempenho nos últimos anos do mercado de trabalho, os salários são baixos, o salário médio cresce pouco, os ambientes de trabalho são extremamente autoritários, e há pouco emprego para jovens entrantes na população economicamente ativa. 
O mais importante é que esse caldo de cultura que descrevemos cresce a cada dia e se apresenta mesmo em municípios menores. Falamos do tráfico mas há muitas formas de violência que passam longe dele como a das crianças e mulheres subjugadas em seu próprio lar. O dia a dia é penoso e crescem ocorrências de sequestros, assaltos, assassinatos, a um ponto que se teme sempre pela vida própria e dos familiares.

Um acordo que foi feito com os grandes jornais de Curitiba por um grupo de profissionais médicos e psicólogos é a não divulgação de suicídios na cidade. Percebia-se que a cada notícia, o número de suicídios crescia nos dias subseqüentes, provavelmente havia um efeito indutor sobre pessoas que pensavam em tomar uma decisão sobre a própria vida. Talvez as constantes notícias sobre a violência e a impunidade e desleixo real com que ela vem sendo tratada incitem novos atos de violência numa espiral. Entretanto, evidentemente, não se trata aí de notícias que possam ser ocultadas.

Entretanto, qual o efeito real da super-exploração pela mídia do assassinato da menina Isabella e o seqüestro e morte de Eloá? Especialmente numa mídia televisiva e noticiosa que se acostumou com a transmissão cultural da violência dos filmes e da mídia norte-americana? É clara no Brasil a influência cultural de um ethos violento norte-americano.

Esses problemas não existiam até a década de oitenta. $\mathrm{O}$ desmoronamento do mercado de trabalho nos anos noventa, o crescente individualismo e a cultura do dinheiro, num contexto mundial que se somou à falta de políticas no campo e na cidade, como reforma agrária, previdência social mais abrangente, melhoria da qualidade no serviço público e outras, levaram a esse estado de coisas explosivo neste início de século XXI.

Esse quadro faz parte do nosso descuido para com a natureza e para com os mais pobres, a crueldade para com os animais e uma cultura mundial na qual os aspectos da violência sejam abertos na forma de guerras, sejam mais estetizados na forma de filmes e produtos culturais valorizando a força pessoal, a capacidade de se valer por si e dispensar laços de solidariedade e comunitários. Essa não é uma pregação moralizante, mas mostra o quanto a moral e a ética se afastaram de nossas vidas em um mundo que aos poucos parece desmoronar. 